\title{
The effect of pH on morphological and physiological root traits of Lupinus angustifolius treated with struvite as a recycled phosphorus source
}

\author{
Ana A. Robles-Aguilar (D) - Jiayin Pang (D) \\ Johannes A. Postma (1D - Silvia D. Schrey $(\mathbb{D} \cdot$ \\ Hans Lambers $\mathbb{D} \cdot$ Nicolai D. Jablonowski $\mathbb{D}$
}

Received: 15 March 2018 / Accepted: 15 August 2018/Published online: 18 September 2018

(C) The Author(s) 2018

\begin{abstract}
Aims Phosphorus (P) recovery from specific waste streams is necessary to develop environmentally sustainable and efficient fertilizers, achieving maximum productivity with minimum losses. A promising example of a $\mathrm{P}$ recovery product is struvite $\left(\mathrm{MgNH}_{4} \mathrm{PO}_{4} \cdot 6 \mathrm{H}_{2} \mathrm{O}\right)$. Phosphorus availability from struvite is profoundly influenced by soil $\mathrm{pH}$ and/or processes in the rhizosphere. Root exudates (e.g., organic anions) and root morphology affect fertilizer bioavailability. The overall objective of our study was to identify root morphological and physiological traits of the narrow-leaf lupine (Lupinus angustifolius L. subsp. angustifolius, cultivar: blau "Boregine") involved in the acquisition of $\mathrm{P}$ from
\end{abstract}

Responsible Editor: Peter Christie.

Electronic supplementary material The online version of this article (https://doi.org/10.1007/s11104-018-3787-2) contains supplementary material, which is available to authorized users.
A. A. Robles-Aguilar · J. A. Postma · S. D. Schrey •
N. D. Jablonowski $(\bowtie)$
Forschungszentrum Jülich GmbH, Institute of Bio- and Geosciences, IBG-2: Plant Sciences, 52425 Jülich, Germany e-mail: n.d.jablonowski@fz-juelich.de
J. Pang
School of Agriculture and Environment, and the UWA Institute of Agriculture, The University of Western Australia, Perth, WA 6001, Australia

\section{H. Lambers}
School of Biological Sciences, and Institute of Agriculture, The University of Western Australia, Perth, WA 6001, Australia

struvite, compared with $\mathrm{KH}_{2} \mathrm{PO}_{4}$ as a soluble $\mathrm{P}$ source. The study included different $\mathrm{pH}$ conditions, as soil $\mathrm{pH}$ is one of the main factors affecting $\mathrm{P}$ availability.

Methods Narrow-leaf lupine plants were grown in river sand under three $\mathrm{pH}$ conditions $(4.5,6.5$ and 7.5). Three different $\mathrm{P}$ treatment conditions were used: 1) $\mathrm{KH}_{2} \mathrm{PO}_{4}$ (KP); 2) $\mathrm{MgNH}_{4} \mathrm{PO}_{4} \cdot 6 \mathrm{H}_{2} \mathrm{O}$ (Struvite), both supplied at $15 \mu \mathrm{g} \mathrm{P} \mathrm{g}^{-1}$ dry sand; and 3) no $\mathrm{P}$ addition (Nil-P), as control. Organic acids in the rhizosheath were collected. Root morphological parameters such as specific root length and root diameter were analyzed.

Results There was no significant difference in total plant biomass detected under any $\mathrm{pH}$ condition between struvite and KP treatments. In both acidic and alkaline conditions, the P-uptake efficiency (PUE: mg P plant ${ }^{-1} / \mathrm{cm}^{2}$ root surface area) with struvite was significantly greater than with KP. At neutral $\mathrm{pH}$, there was no difference in PUE between plants supplied with KP or struvite. Plants growing at neutral $\mathrm{pH}$ showed greater root exudation of carboxylates (mainly citrate) when struvite was added compared with KP. At alkaline $\mathrm{pH}$, the exudation per unit root surface area was greater than that at acidic or neutral $\mathrm{pH}$. Plants growing in acidic $\mathrm{pH}$ had a higher specific root length (SRL) compared with those grown at alkaline or neutral $\mathrm{pH}$.

Conclusions Similar P-uptake efficiency from struvite and $\mathrm{KH}_{2} \mathrm{PO}_{4}$ at neutral $\mathrm{pH}$ in conjunction with the higher total biomass compared to the Nil-P treatment (70\% higher) suggests very effective mobilization of $\mathrm{P}$ from struvite by carboxylate exudation. Application of struvite, while taking into account the different 
strategies for nutrient mobilization, can increase the use efficiency of this recovered $\mathrm{P}$ source.

Keywords Carboxylate exudation · Fertilizer-use efficiency $\cdot$ Struvite $\cdot$ Recycled phosphorus $\cdot$ Rhizosphere $\mathrm{pH} \cdot$ Root diameter $\cdot$ Specific root length

$\begin{array}{ll}\text { Abbreviations } \\ \text { DCL } & \text { Diameter class length } \\ \text { DM } & \text { Dry mass } \\ \text { Nil-P } & \text { No phosphorus treatment } \\ \text { P } & \text { Phosphorus } \\ \text { PUE } & \text { Phosphorus uptake efficiency } \\ \text { SRL } & \text { Specific root length }\end{array}$

\section{Introduction}

Phosphorus (P) is an essential macro-element and plays a crucial role in many key processes (Jouhet et al. 2007; Misson et al. 2005). The total amount of $P$ in soil is generally high after fertilization, but a large portion is not in solution and thereby not directly available to plants. Recovery of the P supplied by fertilizers is thereby a slow process which takes years of cropping. In the first year after application, crops often take up less than $30 \%$ of the applied P (Vance et al. 2003). This is due to precipitation reactions with $\mathrm{Ca}, \mathrm{Fe}, \mathrm{Al}$ and $\mathrm{Mn}$ as well as sorption to clays, $\mathrm{Fe}$ or $\mathrm{Al}$ oxides and hydroxides present in soil, thus making P unavailable for plants (Shen et al. 2011). Furthermore, the conversion of $P$ into organic forms (immobilization by the microbial community) (Balemi and Negisho 2012) may also further constrain the $\mathrm{P}$ availability to plants (Delgado and Scalenghe 2008). This is because the bioavailability of $\mathrm{P}$ from organic pools is mainly determined by the susceptibility of these compounds to plant and microbial phosphatases (Sanyal and De Datta 1991).

Application of large amounts of mineral $\mathrm{P}$ fertilizers derived from rock phosphate is the most common way to enhance plant-available $\mathrm{P}$ in regions with $\mathrm{P}$-deficient soils. However, as a non-renewable natural resource, global rock phosphate reserves are being depleted (Cordell and White 2011). Therefore a move towards a more efficient and sustainable fertilization requires a change in the P stewardship (Fixen and Johnston 2012) by identifying alternative $P$ sources and evaluating their potential as $\mathrm{P}$ fertilizers.
A promising example of an alternative source of $\mathrm{P}$ investigated in this study is struvite $\left(\mathrm{MgNH}_{4} \mathrm{PO}_{4} \cdot 6 \mathrm{H}_{2} \mathrm{O}\right)$, a precipitate recovered from municipal wastewater streams that is free of contaminants and has a stable nutrient composition. Struvite has previously been proposed as a slow-release fertilizer (Rahman et al. 2014). The slow release can ensure a steady nutrient supply for plants which might promote root development in the early stages and improve nutrient-use efficiency (defined by Blair (1993) as the ability of a genotype to acquire nutrients from growth medium and/or utilize them for the production of shoot and root biomass), consequently stimulating plant growth.

A key factor for the management of struvite and similar recycled $\mathrm{P}$ sources is to increase the bioavailability and plant $\mathrm{P}$-uptake efficiency (uptake per unit of root surface area) under different soil conditions. Struvite fertilizers can increase biomass in maize (Zea mays) and narrow-leaf lupine (Lupinus angustifolius) in acidic conditions (Robles-Aguilar et al., unpublished results). However, contrary to the highly soluble commercial P fertilizers (i.e., potassium phosphate - KP), which are bioavailable over a broad $\mathrm{pH}$ range, uptake of $\mathrm{P}$ from struvite is slow at neutral to alkaline $\mathrm{pH}$ (Bhuiyan et al. 2007; Massey et al. 2009). Therefore, knowing how to increase struvite P-use efficiency at different soil $\mathrm{pH}$ values will make its use more reliable as a substitute for rock phosphate. This will improve the management of recycled $\mathrm{P}$ sources which is desirable from both an economic and an environmental perspective (Manske et al. 2001; Shenoy and Kalagudi 2005).

Plants have evolved a number of strategies to improve their P-acquisition efficiency (Lambers et al. 2006; Raghothama and Karthikeyan 2005). Three main strategies are i) changes in the relative investment in root to shoot biomass, ii) root-morphological changes that improve $\mathrm{P}$ acquisition by increasing the soil volume that is explored (Lynch 2007), and iii) P-mining strategies to enhance the solubility of $\mathrm{P}$ from sparingly-available sources by root exudates (organic anions) (Richardson et al. 2011). Significant morphological traits that affect $P$ acquisition include the increase of root surface area through higher root branching density and longer root hairs that enable foraging for plant-available $\mathrm{P}$ and its uptake from the soil solution (Hammond et al. 2004). But also changes in root architecture including growth of roots in regions with higher $\mathrm{P}$ availability are important strategies (Postma et al. 2014). One noteworthy physiological adaptation to increase the $\mathrm{P}$ recovery is 
the exudation of carboxylates (low molecular weight organic anions) into the rhizosphere when plants experience P deficiency (Richardson et al. 2011; Veneklaas et al. 2003). Most likely, plants can adjust at both levels by carboxylate exudation, as well as modifying root morphology (Pearse et al. 2006). Narrow-leaf lupine is well known for its ability to grow well in sandy acidic soils that contain low $\mathrm{P}$ concentrations. This is attributed to its high capability to exude carboxylates, allowing the mobilization of sparingly soluble $\mathrm{P}$ sources in the soil (Pearse et al. 2006). However, no proteoid roots are produced by narrow-leaf lupine, implying that the exudation of carboxylates is not associated with the formation of proteoid roots. Hence, we hypothesized that narrow-leaf lupine can compensate for the low availability of struvite-P at neutral to alkaline conditions not only through carboxylate exudation, but also through specific root morphological adaptations. Therefore, we evaluated if narrow-leaf lupine produces more biomass when struvite is supplied as a P source in sandy soil under different $\mathrm{pH}$ conditions ranging from acidic to alkaline. The strategy of growing P-efficient crops with specific root traits has previously been used in poor soils which accumulate large amounts of plant-unavailable $P$, to enable the mobilization of insoluble/organic $\mathrm{P}$ (Gahoonia and Nielsen 1996).

The objective of this study was 1) to quantify the plasticity of root morphological and physiological traits of narrow-leaf lupine when fertilized with struvite $\left(\mathrm{MgNH}_{4} \mathrm{PO}_{4} \cdot 6 \mathrm{H}_{2} \mathrm{O}\right)$ compared with a conventional $\mathrm{P}$ fertilizer $\mathrm{KH}_{2} \mathrm{PO}_{4}(\mathrm{KP})$ supplied as the control, and 2) to analyze the interaction between $\mathrm{P}$ source and soil $\mathrm{pH}$.

\section{Materials and methods}

\section{Plant cultivation}

The experiment was carried out during 6 weeks from February to March 2016 in a temperature-controlled glasshouse under natural light conditions at the University of Western Australia, Perth, Australia $\left(31.57^{\circ} \mathrm{S}\right.$, $115.47^{\circ} \mathrm{E}$ ) with an average daytime temperature of $24^{\circ} \mathrm{C}$ and average nighttime temperature of $21^{\circ} \mathrm{C}$, and a mean relative humidity of $65 \%$. Pure coarse river sand was washed, sterilized and air-dried. It was found to it contained trace amounts of nutrients as indicated by Pang et al. (2010) with $3 \mu \mathrm{g} \mathrm{g}^{-1}$ bicarbonate extractable $\mathrm{P}$ (Colwell 1963) (16\% of the total P after fertilization), and had an initial $\mathrm{pH}$ of 6.3 analyzed in a solution of $0.01 \mathrm{M} \mathrm{CaCl}_{2}$ (Ahern et al. 1995). To obtain a pH of 4.5 and 7.5 , the sand was mixed with $3 \mathrm{~g}$ iron sulfate $\mathrm{kg}^{-1}$ sand $\left(\mathrm{FeSO}_{4}\right)$ or $50 \mathrm{~g}$ calcium carbonate $\mathrm{kg}^{-1}$ sand $\left(\mathrm{CaCO}_{3}\right)$ in an end-over-end shaker for $15 \mathrm{~min}$ at $99 \mathrm{rpm}$, respectively; these amounts were determined beforehand to reach the desired $\mathrm{pH}$. Pots $(8.5 \times 8.5 \times$ $18 \mathrm{~cm}$ ) were filled with $1.3 \mathrm{~kg}$ of sand with $\mathrm{pH}$ of either $4.5,6.5$ or 7.5 . To ensure that the nutrient supply was adequate for plant growth for the duration of the experiment, all essential nutrients other than $\mathrm{P}$ were provided via a nutrient solution to a final concentration of $30 \mathrm{~N}$, $40 \mathrm{~S}, 24 \mathrm{Ca}, 11.5 \mathrm{Mg}, 0.5 \mathrm{Cu}, 5 \mathrm{Fe}, 55 \mathrm{Cl}$, and $80 \mathrm{~K}$, all values given in $\mu \mathrm{g} \mathrm{g}^{-1}$ dry sand. In order to evaluate the $\mathrm{P}$ recovery from struvite, we used $\mathrm{KH}_{2} \mathrm{PO}_{4}(\mathrm{KP})$, a soluble form of $\mathrm{P}$ as the control. Three $\mathrm{P}$ treatments were applied: i) $\mathrm{KH}_{2} \mathrm{PO}_{4}$ was added as a nutrient solution; ii) struvite $\left(\mathrm{MgNH}_{4} \mathrm{PO}_{4} \cdot 6 \mathrm{H}_{2} \mathrm{O}\right)$ in powder form was mixed with sand, both to a final concentration of $15 \mu \mathrm{g} \mathrm{P} \mathrm{g}^{-1}$ of dry sand; and iii) no P addition (Nil-P), as the control. The supply of appropriate concentrations of $\mathrm{NH}_{4} \mathrm{NO}_{3}$ and $\mathrm{K}_{2} \mathrm{SO}_{4}$ to the $\mathrm{P}$ treatments evened out the nitrogen and potassium provided by the struvite and the $\mathrm{KH}_{2} \mathrm{PO}_{4}$ treatment respectively. The $\mathrm{pH}$ of the nutrient solution was adjusted from the original $\mathrm{pH} 4.5$ to a neutral solution ( $\mathrm{pH}$ 6.5) by adding $10 \mathrm{ml} \mathrm{KOH}$ $(200 \mathrm{mM}) \mathrm{L}^{-1}$ solution, and to an alkaline solution (pH 8) by adding $25 \mathrm{ml} \mathrm{KOH}(200 \mathrm{mM}) \mathrm{L}^{-1}$ solution, in order to maintain the desired $\mathrm{pH}$ in the sand after its application. The sand was initially moistened to $80 \%$ of field capacity with nutrient solution, which was adjusted to the respective $\mathrm{pH}$. Thereafter, soil moisture was maintained for the duration of the experiment by watering pots to a specific weight with deionized water every other day. Watering was controlled to make sure that no water leached from the bottom of the pots.

Three seedlings of narrow-leaf lupine (Lupinus angustifolius L. subsp. angustifolius, cultivar: blau "Boregine", Kiepenkerl, Germany) were planted in each pot and thinned to one plant per pot after 1 week. Each pot was inoculated with $1 \mathrm{~g}$ of peat-based Group G Rhizobium solution (New Edge Microbials, Albury, NSW, Australia). The inoculation was done by applying a few drops to the seedlings using a plastic syringe containing a mixture of rhizobia in peat and water. There were nine treatment combinations in the study, with five replicates per treatment. In addition, two pots without plants were used as control for each treatment to monitor the sand $\mathrm{pH}$ development during 
the experiment. Pots on the greenhouse bench were randomized every second day.

Rhizosheath carboxylates extraction

After 6 weeks, the plants were removed from the pots, and the root systems were shaken gently. The sand that was attached to the roots was defined as the rhizosheath (Pang et al. 2017). Rhizosheath extracts for the analyses of carboxylates were collected according to Pang et al. (2010). The entire root system was submerged in $0.2 \mathrm{mM} \mathrm{CaCl}_{2}$ and shaken to remove the rhizosheath sand. The volume of $\mathrm{CaCl}_{2}$ needed to cover the whole root system varied according to the root size from 20 to $100 \mathrm{ml}$. Subsamples of the extracts were taken and filtered through a $0.22 \mu \mathrm{m}$ syringe filter. One $\mathrm{ml}$ of the filtered extract was transferred into a $1 \mathrm{ml}$ highperformance liquid chromatography (HPLC) vial. HPLC analysis of the extracts was performed as described by Cawthray (2003) using working standards of malic, malonic, lactic, acetic, maleic, citric, succinic, cis-aconitic and trans-aconitic acid (ICN Biomedicals Inc., Aurora OH, USA) to identify and quantify carboxylates.

\section{Plant measurements}

Immediately after collection of carboxylates, plants were separated into shoots and roots, and leaf area was measured using a leaf area meter (LI-3100, LI-COR, Lincoln, Nebraska, USA). Subsequently, cleaned roots were scanned with a transparent adapted tray (acrylic box) positioned in the scanner (Epson Expression Scan 1680, Long Beach, Canada). Roots were spread out in the acrylic box (size A4) containing tap water to minimize the number of overlaps. Based on the scanned images of the root systems, total length, mean diameter, total surface area, and root volume were measured using the WinRHIZOTM regular V.2009 software (Regent Instruments Inc., Quebec, Canada). The root length measurements were partitioned into five diameter classes: $<0.5,0.5-1,1-1.5,1.5-2$, and $>2 \mathrm{~mm}$. The following parameters were based on observed and/or computed data: root-to-shoot ratio (root dry mass/shoot dry mass), specific root length $(\mathrm{SRL})=$ root length/root dry mass $\left(\mathrm{m} \mathrm{g}^{-1}\right)$ and relative diameter class length $(\mathrm{rDCL})=$ $\mathrm{DCL} /$ total root length (yielding a proportion of root length to normalize disparity between plant sizes). Visual scoring of nodulation was done at harvest using the Field guide for nodulation and nitrogen fixation (BC Ministry of Forests 1991). Shoot and root dry mass was recorded after drying for $48 \mathrm{~h}$ at $65^{\circ} \mathrm{C}$ in a forced-draft oven.

\section{Phosphorus analyses}

To determine $\mathrm{P}$ concentrations, dried shoot and root samples were milled using a stainless steel ball mill. Weighed subsamples of the fine powder (200 mg) were digested using a hot concentrated nitric-perchloric (3:1) acid mixture. Total $\mathrm{P}$ concentrations in the shoot and root samples were determined by the malachite green method (Motomizu et al. 1983) using a UV-VIS spectrophotometer (Shimadzu Corporation, Japan). Phosphorus-uptake efficiency (PUE) was calculated based on Hammond et al. (2009), who described PUE as the increase of plant total $P$ content per unit of added $\mathrm{P}$ fertilizer ( $\mathrm{g}$ P plant ${ }^{-1} \mathrm{~g}^{-1} \mathrm{P}$ fertilizer). We modified the formula, normalizing the $\mathrm{P}$ uptake per unit of root surface area instead of per amount of $\mathrm{P}$ applied (PUE: $\mathrm{mg} P$ plant ${ }^{-1} \mathrm{~cm}^{-2}$ root surface area).

\section{Statistical analyses}

Analyses were performed using the statistical program R.2.16.3 (R: A Language and Environment for Statistical Computing (2012) http://www.R-project.org/). Measurements were compared with two-way analysis of variance (ANOVA). Tukey's HSD post hoc test after ANOVA at a significance level of $p<0.05$ was used to check which level of a factor differed from one another. Data were calculated as arithmetic means \pm standard error of the mean of the indicated replicates. Statistical analyses for slopes were conducted by analyses of covariance (ANCOVA). Details of all statistical analyses and data are provided as an electronic supplementary material (ESM) file.

\section{Results}

The effect of struvite-P fertilizer on shoot growth

When P was supplied, plant growth and shoot biomass varied significantly among the $\mathrm{pH}$ conditions (Fig. 1a, exemplary for struvite fertilization). The ANOVA showed significant effects $(p<0.05)$ of both factors, $\mathrm{P}$ treatment and $\mathrm{pH}$, as well as their interactions $(p<0.05)$ in shoot biomass (electronic supplementary material, 


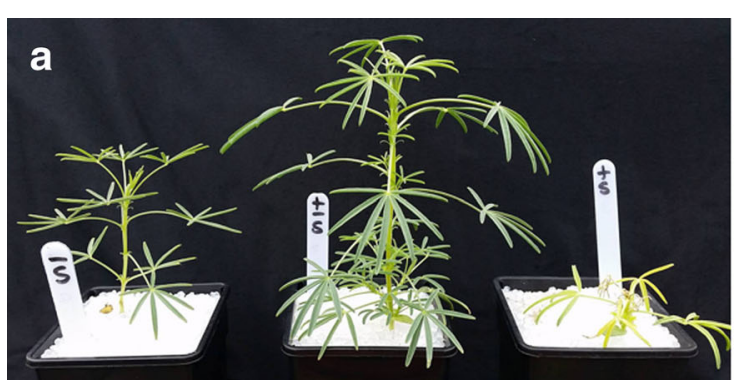

Fig. 1 a Effects of $\mathrm{pH}$ on narrow-leaf lupine growth under struvite treatment in acidic ( $\mathrm{pH} 4.5$, left), neutral ( $\mathrm{pH} 6.5$, middle), and alkaline ( $\mathrm{pH} 7.5$, right) sand. b Effects of different phosphorus

ESM Tables 1 and 2). The similar effectiveness of struvite compared with KP was confirmed at neutral (pH 6.5) and acidic ( $\mathrm{pH} 4.5)$ conditions (Fig. 1b as exemplary for neutral $\mathrm{pH}$, and Fig. 2). Under both pH 6.5 and 4.5, shoot biomass did not differ between struvite- and KP-treated plants. Shoot biomass under both $\mathrm{P}$ treatments was greater than that in the Nil-P treatment $(p<0.05)$ (Fig. 2). At alkaline conditions, there was no difference between P-treated plants and the Nil-P treatment. Leaf area showed a similar trend to that of shoot biomass.

Both high and a low soil $\mathrm{pH}$ significantly reduced plant growth compared to plants growing at neutral $\mathrm{pH}$ $(p<0.05)$. At $\mathrm{H} 7.5$, the total biomass was $80 \%$ less compared to growth at neutral $\mathrm{pH}$. At $\mathrm{pH} 4.5$, the biomass was $65 \%$ less compared to growth at

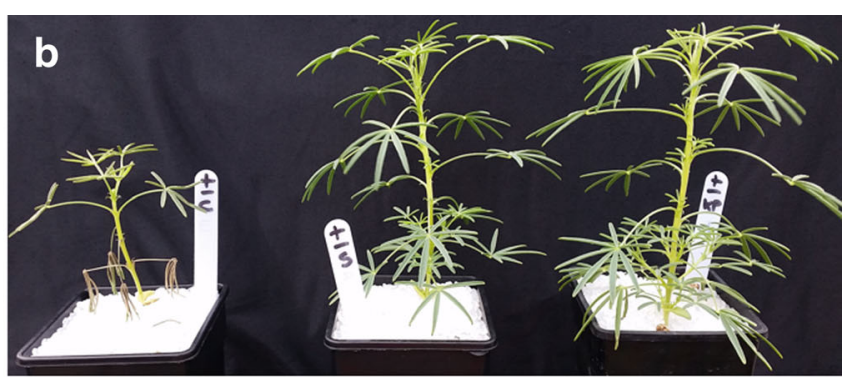

sources applied on narrow-leaf lupine growth at neutral $\mathrm{pH}$ treated with no phosphorus (Nil-P, left), struvite (middle), and potassium phosphate (KP, right)

neutral $\mathrm{pH}$ 6.5, which was the optimum $\mathrm{pH}$ for narrow-leaf lupine.

The allometric analyses offers a visual description of root and shoot biomass distribution, which is not confounded by plant size. Figure 3 shows the root:shoot relationship under different $\mathrm{pH}$ values and $\mathrm{P}$ sources. ANCOVA analyses showed significant differences in slope $(p<0.05)$ between the Nil-P treatment and the other $\mathrm{P}$ sources, as well as between the alkaline $\mathrm{pH}$ compared with acidic and neutral pH (ESM Tables 7 and 8). This allocation pattern shows that the plants invested relatively more in roots when the $\mathrm{pH}$ of the sand was suboptimal for growth (alkaline) or when no $\mathrm{P}$ was applied (Nil-P) (Fig. 3). The results indicate that the effect of struvite was similar to that of KP-P in terms of allocation, as well as total biomass.
Fig. 2 Plant biomass of narrowleaf lupine grown with different phosphorus $(\mathrm{P})$ sources: struvite (S), potassium phosphate (KP) and no $\mathrm{P}$ (Nil-P) applied at different sand $\mathrm{pH}$ (acidic 4.5, neutral 6.5 and alkaline 7.5). The line that divides the box represents the median of the data. The end of the box shows the upper and lower quartiles. The extreme lines out of the box show the highest and lowest value excluding outliers (shown as dots); $n=5$

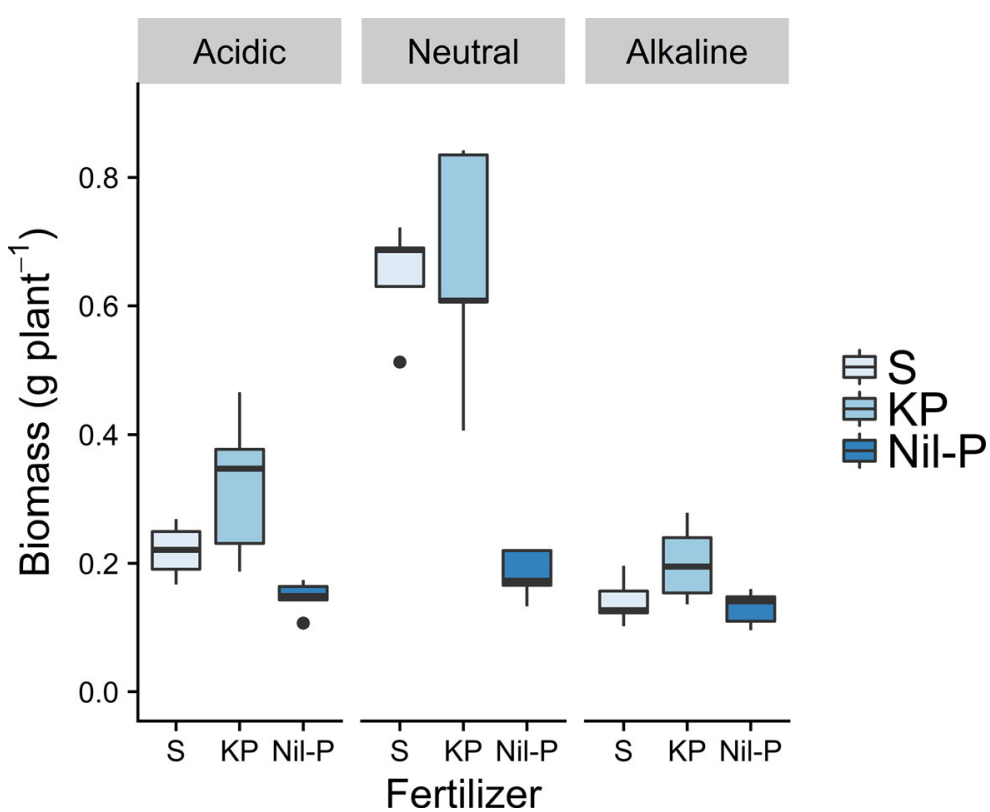


Fig. 3 Allometric analyses of shoot:root biomass distribution of narrow-leaf lupine (logtransformed shoot:root distribution of the dry mass) as affected by $\mathrm{pH}$ : a acidic ( $\mathrm{pH} 4.5)$, neutral ( $\mathrm{pH} 6.5)$ and alkaline ( $\mathrm{pH} 7.5) ; \mathbf{b}$ and the phosphorus source applied (struvite (S), potassium phosphate (KP) and no phosphorus (Nil-P)); Higher slope at alkaline $\mathrm{pH}$ and Nil-P indicated that plants invested more in root than in shoot biomass
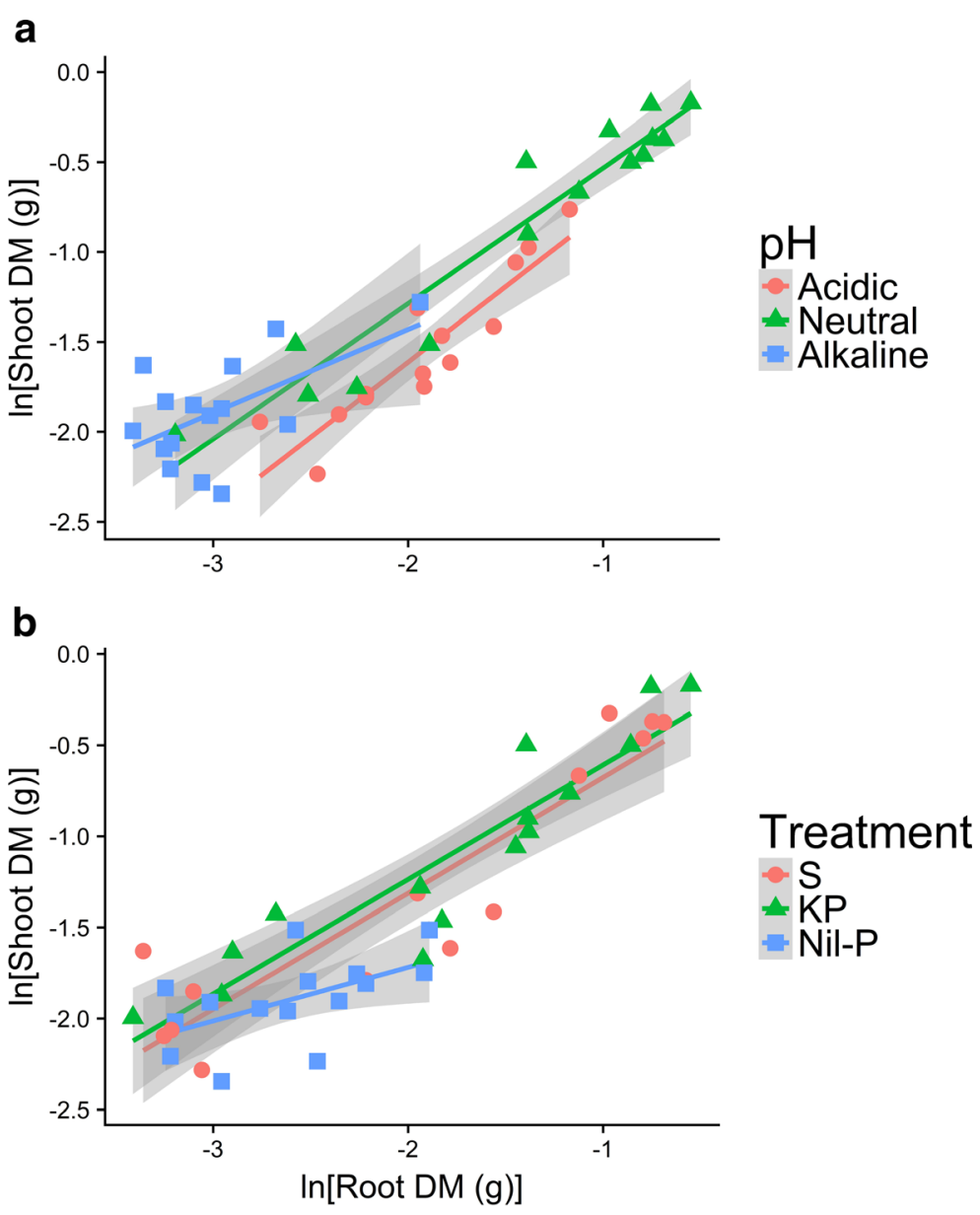

Plant P-uptake efficiency as affected by $\mathrm{pH}$ and phosphorus source applied

Total P content (mg P plant ${ }^{-1}$ ) increased corresponding with the solubility of the P source (Table 1). As a result, the highest total $\mathrm{P}$ content was found in plants treated with KP, which is the most soluble P source, followed by struvite and Nil-P, which is further reflected by biomass production (Fig. 2). The highest plant total $\mathrm{P}$ content and plant growth was observed at neutral $\mathrm{pH}$. Plant $\mathrm{P}$ concentration ( $\mathrm{mg} \mathrm{P} \mathrm{g}^{-1}$ dry mass) showed a different pattern (Table 1). Plants treated with struvite had a higher $\mathrm{P}$ concentration than those treated with KP (significant only at alkaline $\mathrm{pH}$ ). In contrast to plant biomass, plants growing at alkaline $\mathrm{pH}$ had the highest $\mathrm{P}$ concentration, followed by those at acidic and neutral $\mathrm{pH}$ (Table 1). Further statistical data and analyses are provided as electronic supplementary material, ESM Tables 9 and 10.

The P-uptake efficiency was calculated to compare the efficiency of the plants to take up P per unit of root surface area, as an indicator of other physiological processes occurring in the root that might increase the efficiency of $\mathrm{P}$ uptake.

ANOVA analyses indicated significant effects of $\mathrm{P}$ treatment and $\mathrm{pH}$ on PUE $(p<0.05)$. At neutral $\mathrm{pH}$, there was no difference in PUE between KP and struvite. In acidic and in alkaline conditions, PUE from struvite was higher than that from KP (Table 2). At alkaline $\mathrm{pH}$, the PUE was higher than that in the other $\mathrm{pH}$ conditions. Further statistical data and analyses are provided as electronic supplementary material, ESM Tables 13 and 14.

\section{Root morphology}

The root system, in general, was dominated by the taproot and primary lateral roots (first-order branches); however, significant differences in the rooting pattern were observed among $\mathrm{pH}$ conditions (Fig. 4). 
Table 1 Shoot and root phosphorus concentration $\left(\mathrm{mg} \mathrm{P} \mathrm{g}^{-1}\right.$ dry mass, DM) of narrow-leaf lupine plants treated with potassium phosphate (KP), struvite or no phosphorus application (Nil-P) growing at acidic $(\mathrm{pH} 4.5)$, neutral $(\mathrm{pH}$ 6.5) and alkaline $(\mathrm{pH} 7.5)$ conditions in sand; mean values $(n=5)$ with the same letter across shoot or root biomass are not significantly different based on Tukey Honest Sign. Diff. test $(p<0.05)$

\begin{tabular}{|c|c|c|c|c|}
\hline & \multirow[b]{2}{*}{ P source } & \multicolumn{3}{|c|}{$\mathrm{P}$ concentration $\left(\mathrm{mg} \mathrm{g}^{-1} \mathrm{DM}\right)$} \\
\hline & & Acidic & Neutral & Alkaline \\
\hline \multirow[t]{3}{*}{ Shoot } & Struvite & $11.8 \mathrm{~b}$ & $5.6 \mathrm{~b}$ & $22.4 \mathrm{a}$ \\
\hline & $\mathrm{KP}$ & $6.6 \mathrm{~b}$ & $4.6 \mathrm{~b}$ & $10.2 \mathrm{~b}$ \\
\hline & Nil-P & $8.3 \mathrm{~b}$ & $7.9 \mathrm{~b}$ & $12.7 \mathrm{~b}$ \\
\hline \multirow[t]{3}{*}{ Root } & Struvite & $17.9 \mathrm{a}$ & $6.6 \mathrm{c}$ & $15.4 \mathrm{ab}$ \\
\hline & $\mathrm{KP}$ & $6.1 \mathrm{c}$ & $6.7 \mathrm{bc}$ & $9.1 \mathrm{bc}$ \\
\hline & Nil-P & $9.6 \mathrm{abc}$ & $7.4 \mathrm{bc}$ & $8.1 \mathrm{bc}$ \\
\hline
\end{tabular}

Shoot and root values were tested separately. For ANOVA see ESM Table 9 to Table 12

Narrow-leaf lupine plants showed significant variation in total root length and root surface area in response to $\mathrm{pH}$ and $\mathrm{P}$ applied $(p<0.05)$. When plants grew in neutral conditions, total root length and root surface area were greatest with struvite, followed by KP, and the lowest root length and surface area were found when no P was applied (Table 3). In acidic conditions, plants supplied with KP had almost twice more total root length compared with those supplied with struvite $(p<0.05)$. In alkaline $\mathrm{pH}$, secondary roots did not elongate (not growing more than $1.5 \mathrm{~mm}$ from the major axes in most cases), and surface area was reduced by $90 \%$ compared with roots growing at $\mathrm{pH} 6.5$ in all the $\mathrm{P}$ treatments (Table 3). Nodulation was also inhibited at alkaline $\mathrm{pH}$ (data not shown).

Table 2 Phosphorus uptake efficiency (PUE) from struvite, potassium phosphate (KP) and no phosphorus (Nil-P) calculated for narrow-leaf lupine plants growing at acidic ( $\mathrm{pH} 4.5)$, neutral $(\mathrm{pH}$ 6.5) and alkaline $(\mathrm{pH} 7.5)$ conditions in sand depended on an interaction between $\mathrm{P}$ treatment and soil $\mathrm{pH}$. PUE: $\mathrm{mg} \mathrm{P}$ plant ${ }^{-1} \mathrm{~cm}^{-2}$ root surface area

\begin{tabular}{llll}
\hline & \multicolumn{2}{l}{ PUE } & \\
\cline { 2 - 4 } P source & Acidic & Neutral & Alkaline \\
\hline Struvite & $308 \mathrm{ab}$ & $162 \mathrm{c}$ & $1546 \mathrm{a}$ \\
KP & $121 \mathrm{~b}$ & $175 \mathrm{c}$ & $531 \mathrm{a}$ \\
Nil-P & $219 \mathrm{ab}$ & $311 \mathrm{ab}$ & $620 \mathrm{a}$ \\
\hline
\end{tabular}

Values represent the mean of $n=5$. For ANOVA see ESM Table 13
The average root diameter in acidic conditions with struvite was significantly lower compared to KP. For every diameter range, the relative diameter class length was calculated for each $\mathrm{pH}$ (rDCL). Values are shown in Table 4 and represent the percent of the total length that belongs to each root diameter class in each particular $\mathrm{pH}$. At acidic $\mathrm{pH}$, thin roots $(<1 \mathrm{~mm})$ accounted for almost $80 \%$ of total root length, compared with the percentage of thin roots at alkaline $(57 \%)$ and neutral $(71 \%) \mathrm{pH}$. In alkaline conditions, the percentage of thick roots $(>2 \mathrm{~mm})$ increased up to $9 \%$, significantly more than the percentage calculated for neutral $(3.5 \%)$ or acidic $(2.7 \%)$ conditions.

The specific root length (SRL) was significantly affected by $\mathrm{pH}(p<0.05)$, but not by the P treatment ( $p=$ $0.06)$. The highest SRL was found in acidic conditions, with KP, followed by struvite and lowest in Nil-P treatment. The SRL reached its minimum when soil was alkaline, being reduced from $2.4 \mathrm{~m} \mathrm{~g}^{-1}$ root with $\mathrm{KP}$ to $2.0 \mathrm{~m} \mathrm{~g}^{-1}$ root with no $\mathrm{P}$ addition (Table 3). Further statistical data and analyses are provided as electronic supplementary material, ESM Tables 15 to 22 .

\section{Carboxylate release}

At neutral $\mathrm{pH}$, the total amount of carboxylates ( $\mu \mathrm{mol}$ plant $^{-1}$ ), mainly citrate and malate, measured in the rhizosheath of narrow-leaf lupine was significantly increased with struvite treatment in comparison with KP treatment. Under acidic conditions, exudation of carboxylates was less than at neutral $\mathrm{pH}$, with no significant differences between $\mathrm{P}$ sources. At acidic $\mathrm{pH}$, the amount of carboxylates measured was even slightly greater with KP compared with that in the struvite treatment. The carboxylate amount per unit root surface area $\left(\mathrm{mmol} \mathrm{m}^{-2}\right.$ root) was greater as the $\mathrm{pH}$ was increased from 4.5 (acidic) to 7.5 (alkaline) (Fig. 5). At neutral pH (6.5) the exudation was greater in the struvite treatment compared with that in the KP treatment. At alkaline $\mathrm{pH}$, root growth was strongly inhibited, and the total amount of carboxylates was strongly reduced, but the carboxylate amount per unit root surface area was greatest (Fig. 5).

Phosphorus source, $\mathrm{pH}$, and their interaction had a significant effect on the total amount of carboxylates in the rhizosheath $(p<0.05)$ and in the amount per unit of root surface area. Roots modified the exudation of carboxylates, mainly citrate, in response to the different $P$ sources applied, which in turn was affected by the sand $\mathrm{pH}$. 
Fig. 4 Representative images of narrow-leaf lupine at harvest (42 days growth) under different $\mathrm{pH}$ and phosphorus $(\mathrm{P})$ treatments. Struvite, potassium phosphate (KP), and no phosphorus (Nil-P) at acidic (pH 4.5), neutral ( $\mathrm{pH} 6.5$ ) and alkaline ( $\mathrm{pH} 7.5)$ conditions

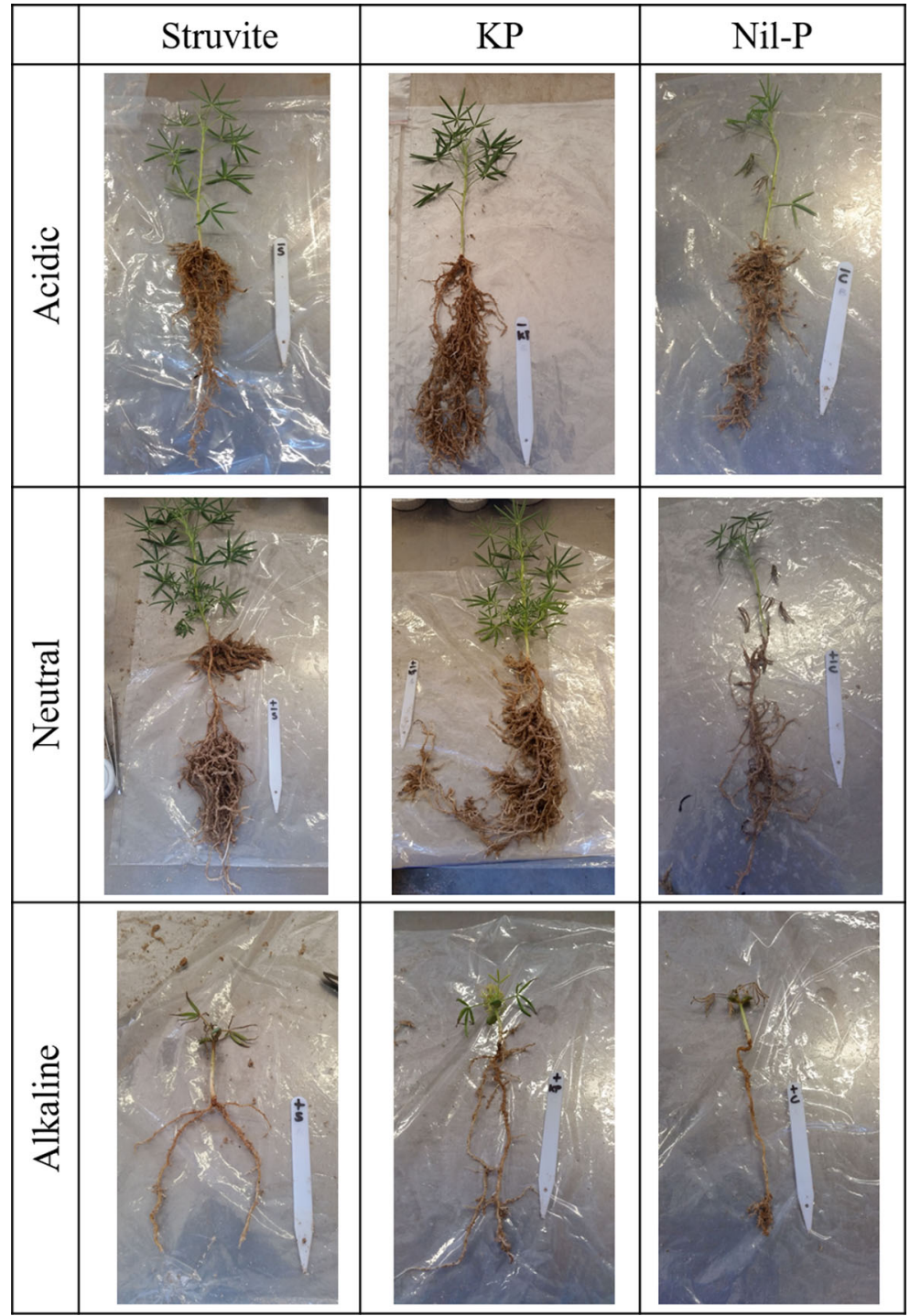

\section{Rhizosheath $\mathrm{pH}$ measurements}

The rhizosheath $\mathrm{pH}$ was significantly affected by the initial $\mathrm{pH}$ condition $(p<0.05)$. In alkaline conditions, the $\mathrm{pH}$ of the rhizosheath of Nil-P plants was higher (8.1) than that of struvite- and KP-treated plants (8 and 7.8 , respectively). Those $\mathrm{pH}$ values were higher than the initial $\mathrm{pH}$ values of the sand at alkaline condition, monitored in the non-planted control pots (7.5). In neutral conditions, $\mathrm{pH}$ of the Nil-P was slightly higher (6.0) compared to struvite (5.6) and KP (5.5). In this case, the $\mathrm{pH}$ measured in the rhizosheath was lower than the initial $\mathrm{pH}$ measured in neutral condition (6.5). In contrast to what observed in alkaline and neutral $\mathrm{pH}$, struvite treatment in acidic conditions slightly increased the $\mathrm{pH}$ (4.9) in comparison with KP (4.2) and Nil-P (4.5). However, no significant difference in rhizosheath $\mathrm{pH}(p=0.2)$ was found between different $\mathrm{P}$ sources.

\section{Discussion}

Root morphology in response to $\mathrm{pH}$ and $\mathrm{P}$ source

The root morphology of narrow-leaf lupine was markedly altered by the soil $\mathrm{pH}$. High $\mathrm{pH}$ inhibited root elongation, with a reduction of up to $90 \%$ in surface area between plants growing at $\mathrm{pH} 7.5$ and $\mathrm{pH} 6.5$, 
Table 3 Total root length, average root diameter, root surface area and specific root length of narrow-leaf lupine supplied with struvite, potassium phosphate (KP), or no phosphorus (Nil-P) in sand at acidic ( $\mathrm{pH} 4.5)$, neutral ( $\mathrm{pH}$ 6.5), and alkaline ( $\mathrm{pH} 7.5)$ conditions; means $(n=5)$ with the same letter for each column are not significantly different

\begin{tabular}{llllll}
\hline $\mathrm{pH}$ & $\begin{array}{l}\text { P } \\
\text { Source }\end{array}$ & $\begin{array}{l}\text { Total } \\
\text { root } \\
\text { length } \\
(\mathrm{cm})\end{array}$ & $\begin{array}{l}\text { Average } \\
\text { root } \\
\text { diam. } \\
(\mathrm{mm})\end{array}$ & $\begin{array}{l}\text { Root } \\
\text { surface } \\
\text { area } \\
\left(\mathrm{cm}^{2}\right)\end{array}$ & $\begin{array}{l}\text { Specific } \\
\text { root length } \\
\left(\mathrm{m} \mathrm{g}^{-1} \text { root }\right)\end{array}$ \\
\hline Acidic & Struvite & $538 \mathrm{~b}$ & $0.8 \mathrm{c}$ & $143 \mathrm{bc}$ & $4.1 \mathrm{a}$ \\
& KP & $1025 \mathrm{a}$ & $1.7 \mathrm{~b}$ & $273 \mathrm{ab}$ & $4.8 \mathrm{a}$ \\
& Nil-P & $404 \mathrm{bc}$ & $0.9 \mathrm{c}$ & $111 \mathrm{c}$ & $4.0 \mathrm{a}$ \\
Neutral & Struvite & $1327 \mathrm{a}$ & $2.6 \mathrm{a}$ & $404 \mathrm{a}$ & $3.2 \mathrm{~b}$ \\
& KP & $1218 \mathrm{a}$ & $2.5 \mathrm{a}$ & $344 \mathrm{a}$ & $3.1 \mathrm{~b}$ \\
& Nil-P & $280 \mathrm{bc}$ & $0.9 \mathrm{c}$ & $82 \mathrm{c}$ & $3.1 \mathrm{~b}$ \\
Alkaline & Struvite & $90 \mathrm{c}$ & $1.1 \mathrm{bc}$ & $30 \mathrm{c}$ & $2.1 \mathrm{c}$ \\
& KP & $165 \mathrm{bc}$ & $1.1 \mathrm{c}$ & $55 \mathrm{c}$ & $2.4 \mathrm{c}$ \\
& Nil-P & $104 \mathrm{bc}$ & $1.2 \mathrm{bc}$ & $39 \mathrm{c}$ & $2.0 \mathrm{c}$ \\
\hline
\end{tabular}

For ANOVA see ESM Tables 15-22

comparable to results previously observed by Tang et al. (1992). Plants growing in acidic $\mathrm{pH}$ had a greater SRL than plants growing in alkaline or neutral $\mathrm{pH}$. A strategy

Table 4 Response variables 1) average root length within a diameter class (DCL) and 2) relative diameter class length $(\mathrm{rDCL})=\mathrm{DCL} /$ root length $(\%)$ of narrow-leaf lupine grown with struvite, potassium phosphate (KP) and no phosphorus (Nil-P) in to increase the overall SRL and therefore presumably increase nutrient uptake is reducing the length while increasing the thickness of the primary root and increasing the length of thin lateral roots (Hammond et al. 2004). For plants growing in acidic $\mathrm{pH}$, thin roots (0.1-1 mm) accounted for almost $80 \%$ of total root length, compared with $57 \%$ under alkaline and $71 \%$ under neutral conditions. This reduction in mean root diameter at acidic $\mathrm{pH}$ is in line with previous studies of relative diameter class length of lupine (Chen et al. 2012), where approximately $70 \%$ of total root length was in the diameter classes between 0.1 and $1.0 \mathrm{~mm}$. Lupine plants in the present study grew well on low-pH sandy soils, but not on neutral to alkaline soils, consistent with results from a previous study (Tang et al. 1992). One of the strategies to grow at low $\mathrm{pH}$ might be the increase of SRL as a consequence of decreasing root diameter, as observed in our experiment in acidic conditions. This might be a beneficial trait to increase $\mathrm{P}$ uptake in acidic $\mathrm{pH}$, as shown previously in a range of species by Hill et al. (2006).

In contrast to what was observed in acidic $\mathrm{pH}$, alkaline conditions modified root morphology by increasing the proportion of thick roots. Usually, thicker roots

sand at acidic (4.5), neutral (6.5) and alkaline (7.5) $\mathrm{pH}$; mean values $(n=5)$ with the same letter within the same root diameter class are not significantly different

\begin{tabular}{|c|c|c|c|c|c|}
\hline \multirow[t]{2}{*}{ Root diameter (mm) } & \multirow[t]{2}{*}{$\mathrm{pH}$} & \multicolumn{3}{|l|}{ DCL } & \multirow[t]{2}{*}{$\operatorname{rDCL}(\%)$} \\
\hline & & Struvite & KP & Nil-P & \\
\hline \multirow[t]{3}{*}{0.5} & Acidic & $127 \mathrm{a}$ & $216 \mathrm{a}$ & $77 \mathrm{bc}$ & 21 \\
\hline & Neutral & $206 \mathrm{a}$ & $188 \mathrm{a}$ & $57 \mathrm{bc}$ & 17 \\
\hline & Alkaline & $19 \mathrm{a}$ & $20 \mathrm{a}$ & $13 \mathrm{c}$ & 15 \\
\hline \multirow[t]{3}{*}{$0.5-1$} & Acidic & $286 \mathrm{a}$ & 599 a & $255 \mathrm{c}$ & 58 \\
\hline & Neutral & $703 a$ & $710 \mathrm{a}$ & $141 \mathrm{~b}$ & 53 \\
\hline & Alkaline & $34 \mathrm{~b}$ & $80 \mathrm{~b}$ & $36 \mathrm{~b}$ & 41 \\
\hline \multirow[t]{3}{*}{$1-1.5$} & Acidic & $142 b c$ & $146 \mathrm{bc}$ & $69 \mathrm{~cd}$ & 16 \\
\hline & Neutral & $286 \mathrm{a}$ & $234 \mathrm{ab}$ & $50 \mathrm{~cd}$ & 19 \\
\hline & Alkaline & $16 \mathrm{~d}$ & $34 \mathrm{~cd}$ & $27 \mathrm{~cd}$ & 21 \\
\hline \multirow[t]{3}{*}{$1.5-2$} & Acidic & $22 \mathrm{bc}$ & $39 \mathrm{bc}$ & $18 \mathrm{bc}$ & 4 \\
\hline & Neutral & $84 \mathrm{a}$ & $54 \mathrm{ab}$ & $18 \mathrm{bc}$ & 5 \\
\hline & Alkaline & $10 \mathrm{c}$ & $17 \mathrm{bc}$ & $15 \mathrm{bc}$ & 12 \\
\hline \multirow[t]{3}{*}{$>2$} & Acidic & $12 \mathrm{~b}$ & $23 a b$ & $14 \mathrm{~b}$ & 2 \\
\hline & Neutral & $46 \mathrm{a}$ & $30 \mathrm{ab}$ & $12 \mathrm{~b}$ & 3 \\
\hline & Alkaline & $8 \mathrm{~b}$ & $11 \mathrm{~b}$ & $10 \mathrm{~b}$ & 8 \\
\hline
\end{tabular}


Fig. 5 Carboxylates recovered in rhizosheath extracts of narrowleaf lupine as affected by the phosphorus source applied (struvite (S), potassium phosphate (KP) and no phosphorus (Nil-P)) growing in sand at acidic ( $\mathrm{pH} 4.5$ ), neutral ( $\mathrm{pH} 6.5$ ) and alkaline ( $\mathrm{pH} 7.5$ ) conditions; the line that divides the box represents the median of the data. The end of the box shows the upper and lower quartiles. The extreme lines show the highest and lowest value excluding outliers (shown as dots); $n=5$

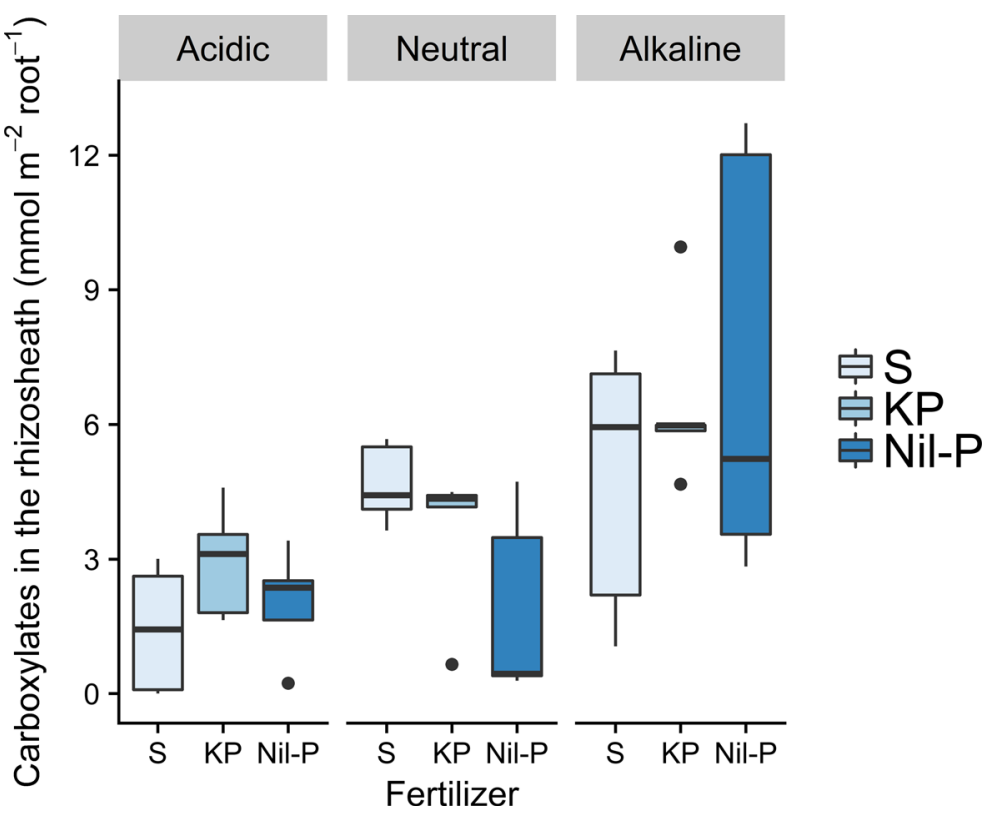

(>2 mm) account for approximately $4 \%$ of total root length (Chen et al. 2012), a similar proportion to what was found at acidic and neutral $\mathrm{pH}$ in the present study. However, at alkaline $\mathrm{pH}$, this increased to $9 \%$. The explanation might not be related to nutrient availability, but to the high $\mathrm{pH}$ itself. Under nutrient stress, an increase of SRL would be expected. However, plants growing in alkaline $\mathrm{pH}$ without $\mathrm{P}$ showed that the development of lateral and secondary roots was strongly inhibited; roots were thicker and mostly belonged to the top root part near the shoot and showed no further lateral root growth.

The SRL was affected by $\mathrm{pH}$ but did not vary among $\mathrm{P}$ applications. Plants with Nil-P showed no significant difference in SRL in comparison with the P-treated plants at the same $\mathrm{pH}$. Differences in total root length between $\mathrm{P}$ applications were only observed in acidic $\mathrm{pH}$. At $\mathrm{pH} 4.5$, the total root length of KP-treated plants almost doubled in comparison with those grown with struvite, despite showing no differences in SRL. To what extent the plant benefits from the increased SRL in terms of additional $\mathrm{P}$ uptake is still a matter of debate (Zobel et al. 2007). As discussed below, narrow-leaf lupine's physiological responses to different $\mathrm{P}$ sources were apparently more pronounced than morphological root modifications.
Physiological root adaptations to $\mathrm{P}$ source applied

Root-induced chemical changes in the rhizosphere or rhizosheath have a distinct effect on the availability of $P$ (Marschner et al. 1986). Our study found that narrowleaf lupine released a greater amount of carboxylates at neutral conditions when struvite was applied than with the readily available KP. We hypothesized that the increase in carboxylates exudation would enhance the bioavailability of $\mathrm{P}$ from struvite because of an increase in P solubility from struvite at lower $\mathrm{pH}$. We observed lower rhizosheath $\mathrm{pH}$ values in neutral condition in comparison with the bulk-sand $\mathrm{pH}$. However, $\mathrm{pH}$ measurements did not differ between the struvite treatment and the easily available KP. Therefore, the effect of an increased $\mathrm{P}$ solubility may be explained also by the displacement of $\mathrm{P}$ from the matrix, in this case of struvite, by anion exchange, as described before for other P sources (Lambers et al. 2006). This agrees with a study by Hinsinger et al. (2003) stating that the contribution of organic acids to acidification is likely less important than the contribution by the cation-anion balance to increased $\mathrm{P}$ solubility.

The exudation of carboxylates depended not only on the $\mathrm{P}$ source applied, but also on the initial soil $\mathrm{pH}$ at which the plants were grown. The total amount of carboxylates was very low in alkaline conditions, because root growth was strongly reduced. Interestingly, a 
greater exudation per root surface area was observed at alkaline $\mathrm{pH}$ without differences between $\mathrm{P}$ treatments. This suggests that at high $\mathrm{pH}$, carboxylate exudation is a key strategy of narrow-leaf lupine to reduce $\mathrm{pH}$ as well as to mobilize $\mathrm{P}$.

Our results agree with those of Talboys et al. (2016) who affirmed that struvite's effectiveness as a P fertilizer is greater for crop species that exude large quantities of organic anions. They compared Triticum aestivum (spring wheat), a species exhibiting little exudation, and Fagopyrum esculentum (buckwheat), a species exhibiting abundant exudation, treated with either struvite, triple-superphosphate or di-ammonium phosphate. They found that buckwheat grew better on struvite than spring wheat did, suggesting that the larger amount of exudates of buckwheat can explain its higher yield and apparent fertilizer recovery (Talboys et al. 2016). Thus, the use of species that release large amounts of exudates would be a good strategy for alkaline soils where struvite is not initially soluble. However, calcicole species that are less sensitive to a high $\mathrm{pH}$ than $L$. angustifolius should be further investigated, e.g., L. pilosus and L. cosentinii (Brand et al. 2002; Ding et al. 2018).

Growth of narrow-leaf lupine under different $\mathrm{pH}$ and $\mathrm{P}$ sources

The response of narrow-leaf lupine to $\mathrm{P}$ application showed substantial differences in biomass under different $\mathrm{pH}$, but no differences among struvite and KP at any $\mathrm{pH}$. Allocation patterns showed that both $\mathrm{P}$ sources are functioning similarly in terms of biomass production. As expected, plant growth was reduced without the addition of $\mathrm{P}$ in all $\mathrm{pH}$ conditions. Likewise, plant growth was inhibited at alkaline conditions, with no significant differences in biomass production among the $\mathrm{P}$ treatments. The chlorosis of old leaves at alkaline $\mathrm{pH}$ or when no $\mathrm{P}$ was supplied was observed in most of the plants, possibly reflecting the process of translocation of $\mathrm{P}$ and other nutrients to young leaves. Other nutrients other than $\mathrm{P}$ were applied at sufficient concentrations for plant growth. Generally, high $\mathrm{pH}$ was not optimal for plant growth; however, the high content of mineral nutrients in large-seeded species like narrowleaf lupine, and their translocation from cotyledons during early growth possibly enabled seedling growth under stress conditions for 2 weeks (Milberg et al. 1998). A pH above 6.0 specifically reduces nodulation in some lupine species (Tang and Robson 1993), as also observed in this experiment at alkaline conditions.

The biomass of narrow-leaf lupine when $\mathrm{P}$ was supplied (indistinctly of the $\mathrm{P}$ form) was $80 \%$ lower at alkaline $\mathrm{pH}$ and $65 \%$ lower at acidic conditions compared with plants grown at $\mathrm{pH} 6.5$. The optimal $\mathrm{pH}$ for growth of narrow-leaf lupine is between 5.0 and 5.5 (Tang et al. 1992), similar to the rhizosheath $\mathrm{pH}$ found in the present study at neutral condition. At acidic $\mathrm{pH}$, the solubility of struvite is higher due to its physicalchemical properties. The struvite crystallization process is affected by several factors such as temperature or $\mathrm{pH}$ (Huchzermeier and Tao 2012). High pH favors the formation of struvite crystals ( $\mathrm{pH}$ range of 7 to 11), whereas low $\mathrm{pH}$ favors its solubilization (Bhuiyan et al. 2007). Therefore, as expected, the effectiveness of struvite and $\mathrm{KP}$ as $\mathrm{P}$-fertilizers at acidic $\mathrm{pH}$ was similar. At neutral $\mathrm{pH}$, the effectiveness of both $\mathrm{P}$ sources was also similar despite the lower solubility of struvite at this $\mathrm{pH}$. Both $\mathrm{P}$ treatments resulted in higher total biomass compared to plants where no P was added, with no significant difference between them. This observation is likely due to the carboxylate exudation by the narrow-leaf lupine roots when struvite was applied, mobilizing the struvite-P at similar rates as the readily soluble KP-P.

Phosphorus-uptake efficiency and P concentration in shoots and roots

As for the biomass, it was expected that $\mathrm{P}$ concentration of narrow-leaf lupine would decrease at high $\mathrm{pH}$, as shown previously in other lupine species grown at a pH above 6 (Jessop and Mahoney 1982). However, narrow-leaf lupine grown in alkaline $\mathrm{pH}$ exhibited significantly higher $\mathrm{P}$ concentration compared with acidic and neutral conditions. At this $\mathrm{pH}$, where plants only reached early developmental stage, $\mathrm{P}$ was likely not the limiting nutrient. In plants grown at lower $\mathrm{pH}$ conditions the $\mathrm{P}$ concentration in old leaves decreased with age (Imo and Timmer 1992), as measured in plants growing in acidic $\mathrm{pH}$.

The P-uptake efficiency (PUE) from struvite at acidic $\mathrm{pH}$ was $60 \%$ greater than that from KP. The higher $\mathrm{P}$ concentration and PUE of struvite-treated plants in acidic $\mathrm{pH}$ was related to a higher SRL of narrow-leaf lupine at acidic $\mathrm{pH}$, but also due to the high solubility of struvite at this $\mathrm{pH}$. The measured shoot $\mathrm{P}$ concentration in the plants grown at alkaline $\mathrm{pH}$ was $22 \mathrm{mg} \mathrm{P} \mathrm{g}^{-1}$ dry 
mass and $11 \mathrm{mg} \mathrm{P} \mathrm{g}^{-1}$ dry mass at acidic $\mathrm{pH}$, both under struvite treatment, which can be considered as toxic (Römheld 2012; Shane et al. 2004a,b). This might explain why struvite-treated plants in acidic conditions were slightly smaller than those treated with KP, as for other lupine species like L. micranthus high sensitivity to $\mathrm{P}$ toxicity has been reported, showing growth inhibition after exposure to a high P supply (Abdolzadeh et al. 2010). This indicates a low capacity to down-regulate the P-uptake system which might also be the case in narrow-leaf lupine, with the increase of the SRL. However, no visual signs of $\mathrm{P}$ or any other nutrient toxicity were observed.

At neutral $\mathrm{pH}$, no difference in PUE was found. This is probably related to the greater exudation of carboxylates in the struvite treatment as discussed above.

We suggest that for plants adapted to neutral or acidic conditions such as narrow-leaf lupine that are able to exude large amounts of carboxylates, no difference in biomass between struvite and KP treatments is expected at those $\mathrm{pH}$ values. Lower amount of struvite than of KP in acidic conditions might be recommended, as the $\mathrm{P}$ concentration in plant tissues measured in the struvite treatment was at the level considered toxic, even though no P-toxicity symptoms were observed.

\section{Conclusions}

The effectiveness of struvite as a $\mathrm{P}$ source can be enhanced in crop species that exude large amounts of carboxylates by $\mathrm{P}$ mobilization via cation exchange. Narrow-leaf lupine released greater amounts of organic anions at neutral $\mathrm{pH}$ when struvite was applied than when the readily available KP was used. Large quantities of malate and citrate were found in the rhizosheath, reaching concentrations in the low $m M$ range. As a consequence, biomass at neutral $\mathrm{pH}$ was similar for plants treated with struvite and with the highly plantavailable KP. This confirms the hypothesis that narrowleaf lupine can increase struvite P solubility, resulting in an enhanced plant $P$ availability. However, this was not observed at alkaline $\mathrm{pH}$, when root growth of the calcifuge narrow-leaf lupine was strongly inhibited. Interestingly, even though the total amount of exudates was low in alkaline conditions, the amount of carboxylates per unit root surface area was even higher than under neutral $\mathrm{pH}$. This suggests that carboxylate exudation is a general strategy of narrow-leaf lupine to acidify the rhizosphere and to mobilize soil P. At acidic $\mathrm{pH}$, plants supplied with struvite had a higher $\mathrm{P}$ concentration and PUE compared to plants supplied with KP, explained by a higher SRL, and also due to the high solubility of struvite at this $\mathrm{pH}$. The $\mathrm{P}$ concentration in plant tissue under acidic conditions can be considered as toxic and might explain why struvite-treated plants grown at this $\mathrm{pH}$ were slightly smaller than those treated with KP.

Our study showed that struvite used as a slow-release fertilizer, could be utilized by crop species with root morphological and physiological strategies to mobilize P from a crop root system. Struvite might be more efficient for the production of biomass compared to conventional highly soluble $\mathrm{P}$ fertilizers, given the consideration of the plant's adaptation to specific $\mathrm{pH}$ conditions.

Acknowledgements The work was conducted within ManureEcoMine project, funded by the European Community's Framework Programme (FP7/2007-2013) under Grant Agreement $\mathrm{n}^{\circ} 603744$. The research was supported by the School of Biological Sciences at the University of Western Australia. We thank Gregory R. Cawthray for running the carboxylates analyses and Patrick E. Hayes, Wenli Ding, Caio Guilherme Pereira, Anna Abrahão, Adrien Frémont, Rodrigo Pires and Lukasz Kotula for their assistance in sample collection and analyses. We kindly thank Vicky M. Temperton for helping to develop the idea and original planning of this experiment. We highly appreciate the final proofreading of the manuscript by Marie Bolger.

Open Access This article is distributed under the terms of the Creative Commons Attribution 4.0 International License (http:// creativecommons.org/licenses/by/4.0/), which permits unrestricted use, distribution, and reproduction in any medium, provided you give appropriate credit to the original author(s) and the source, provide a link to the Creative Commons license, and indicate if changes were made.

\section{References}

Abdolzadeh A, Wang X, Veneklaas EJ, Lambers H (2010) Effects of phosphorus supply on growth, phosphate concentration and cluster-root formation in three lupinus species. Ann Bot 105:365-374

Ahern C, Baker D, Aitken R (1995) Models for relating ph measurements in water and calcium chloride for a wide range of ph, soil types and depths. Plant Soil 171:47-52

Balemi T, Negisho K (2012) Management of soil phosphorus and plant adaptation mechanisms to phosphorus stress for sustainable crop production: a review. J Soil Sci Plant Nutr 12: $547-562$ 
BC Ministry of Forests - Research Branch (1991) Field guide for nodulation and nitrogen fixation

Bhuiyan M, Mavinic D, Beckie R (2007) A solubility and thermodynamic study of struvite. Environ Technol 28: $1015-1026$

Blair G (1993) Nutrient efficiency — what do we really mean? Genetic aspects of plant mineral nutrition. Springer

Brand JD, Tang C, Rathjen AJ (2002) Screening rough-seeded lupins (lupinus pilosus murr. And lupinus atlanticus glads.) for tolerance to calcareous soils. Plant Soil 245:261-275. https://doi.org/10.1023/A:1020490626513

Cawthray GR (2003) An improved reversed-phase liquid chromatographic method for the analysis of low-molecular mass organic acids in plant root exudates. J Chromatogr A 1011: 233-240. https://doi.org/10.1016/S0021-9673(03)01129-4

Chen YL, Dunbabin VM, Diggle AJ, Siddique KH, Rengel Z (2012) Assessing variability in root traits of wild lupinus angustifolius germplasm: basis for modelling root system structure. Plant Soil 354:141-155

Colwell JD (1963) The estimation of phosphorus fertilizer requirements of wheat in southern New South Wales by soil analysis. Aust J Exp Agric Anim Husb 3: 190-197

Cordell D, White S (2011) Peak phosphorus: clarifying the key issues of a vigorous debate about long-term phosphorus security. Sustainability 3:2027-2049

Delgado A, Scalenghe R (2008) Aspects of phosphorus transfer from soils in Europe. J Plant Nutr Soil Sci 171:552-575

Ding W, Clode PL, Clements J, Lambers H (2018) Sensitivity of different lupinus species to calcium under a low phosphorus supply. Plant Cell Environ in press 41:1512-1523

Fixen PE, Johnston AM (2012) World fertilizer nutrient reserves: a view to the future. J Sci Food Agric 92:1001-1005

Gahoonia TS, Nielsen NE (1996) Variation in acquisition of soil phosphorus among wheat and barley genotypes. Plant Soil 178:223-230. https://doi.org/10.1007/Bf00011587

Hammond JP, Broadley MR, White PJ (2004) Genetic responses to phosphorus deficiency. Ann Bot 94:323-332

Hammond JP, Broadley MR, White PJ, King GJ, Bowen HC, Hayden R, Meacham MC, Mead A, Overs T, Spracklen WP (2009) Shoot yield drives phosphorus use efficiency in Brassica oleracea and correlates with root architecture traits. J Exp Bot 60:1953-1968

Hill J, Simpson R, Moore A, Chapman D (2006) Morphology and response of roots of pasture species to phosphorus and nitrogen nutrition. Plant Soil 286:7-19

Hinsinger P, Plassard C, Tang, Jaillard B (2003) Origins of rootmediated $\mathrm{pH}$ changes in the rhizosphere and their responses to environmental constraints: a review. Plant Soil 248(1-2): 43-59

Huchzermeier MP, Tao W (2012) Overcoming challenges to struvite recovery from anaerobically digested dairy manure. Water Environ Res 84:34-41

Imo M, Timmer V (1992) Growth, nutrient allocation and water relations of mesquite (prosopis chilensis) seedlings at differing fertilization schedules. For Ecol Manag 55:279-294

Jessop R, Mahoney J (1982) Effects of lime on the growth and nodulation of four grain legumes. Soil Res 20:265-268

Jouhet J, Marechal E, Block MA (2007) Glycerolipid transfer for the building of membranes in plant cells. Prog Lipid Res 46: 37-55. https://doi.org/10.1016/j.plipres.2006.06.002
Lambers H, Shane MW, Cramer MD, Pearse SJ, Veneklaas EJ (2006) Root structure and functioning for efficient acquisition of phosphorus: matching morphological and physiological traits. Ann Bot 98:693-713

Lynch JP (2007) Roots of the second green revolution. Aust J Bot 55:493-512

Manske G, Ortiz-Monasterio J, Van Ginkel M, Gonzalez R, Fischer R, Rajaram S, Vlek P (2001) Importance of p uptake efficiency versus $\mathrm{p}$ utilization for wheat yield in acid and calcareous soils in Mexico. Eur J Agron 14:261-274

Marschner H, Römheld V, Horst W, Martin P (1986) Root-induced changes in the rhizosphere: importance for the mineral nutrition of plants. J Plant Nutr Soil Sci 149:441-456

Massey MS, Davis JG, Ippolito JA, Sheffield RE (2009) Effectiveness of recovered magnesium phosphates as fertilizers in neutral and slightly alkaline soils. Agron J 101: 323-329

Milberg P, Pérez-Fernández MA, Lamont BB (1998) Seedling growth response to added nutrients depends on seed size in three woody genera. J Ecol 86:624-632

Misson J, Raghothama KG, Jain A, Jouhet J, Block MA, Bligny R, Ortet P, Creff A, Somerville S, Rolland N, Doumas P, Nacry P, Herrerra-Estrella L, Nussaume L, Thibaud MC (2005) A genome-wide transcriptional analysis using arabidopsis thaliana affymetrix gene chips determined plant responses to phosphate deprivation. Proc Natl Acad Sci USA 102: 11934-11939. https://doi.org/10.1073/pnas.0505266102

Motomizu S, Wakimoto T, Toei K (1983) Spectrophotometric determination of phosphate in river waters with molybdate and malachite green. Analyst 108:361-367. https://doi. org/10.1039/an9830800361

Pang J, Ryan MH, Tibbett M, Cawthray GR, Siddique KH, Bolland MD, Denton MD, Lambers H (2010) Variation in morphological and physiological parameters in herbaceous perennial legumes in response to phosphorus supply. Plant Soil 331:241-255

Pang JY, Ryan MH, Siddique KHM, Simpson RJ (2017) Unwrapping the rhizosheath. Plant Soil 418:129-139. https://doi.org/10.1007/s11104-017-3358-y

Pearse SJ, Veneklaas EJ, Cawthray GR, Bolland MD, Lambers H (2006) Carboxylate release of wheat, canola and 11 grain legume species as affected by phosphorus status. Plant Soil 288:127-139

Postma JA, Dathe A, Lynch JP (2014) The optimal lateral root branching density for maize depends on nitrogen and phosphorus availability. Plant Physiol 166:590-602

Raghothama KG, Karthikeyan AS (2005) Phosphate acquisition. Plant Soil 274:37-49. https://doi.org/10.1007/s11104-0042005-6

Rahman MM, Salleh MAM, Rashid U, Ahsan A, Hossain MM, Ra CS (2014) Production of slow release crystal fertilizer from wastewaters through struvite crystallization-a review. Arab J Chem 7:139-155

Richardson AE, Lynch JP, Ryan PR, Delhaize E, Smith FA, Smith SE, Harvey PR, Ryan MH, Veneklaas EJ, Lambers H (2011) Plant and microbial strategies to improve the phosphorus efficiency of agriculture. Plant Soil 349:121-156

Römheld V (2012) Diagnosis of deficiency and toxicity of nutrients. Marschner's Mineral Nutrition of Higher Plants 3rd edn. p 299-312. https://doi.org/10.1016/B978-0-12-3849052.00011-X 
Sanyal SK, De Datta SK (1991) Chemistry of phosphorus transformations in soil. Adv Soil Sci 16:1-120

Shane MW, McCully ME, Lambers H (2004a) Tissue and cellular phosphorus storage during development of phosphorus toxicity in Hakea prostrata (Proteaceae). J Exp Bot 55(399): 1033-1044

Shane MW, Szota C, Lambers H (2004b) A root trait accounting for the extreme phosphorus sensitivity of Hakea prostrata (Proteaceae). Plant Cell Environ 27(8):991-1004

Shen J, Yuan L, Zhang J, Li H, Bai Z, Chen X, Zhang W, Zhang F (2011) Phosphorus dynamics: from soil to plant. Plant Physiol 156:997-1005. https://doi.org/10.1104 /pp.111.175232

Shenoy V, Kalagudi G (2005) Enhancing plant phosphorus use efficiency for sustainable cropping. Biotechnol Adv 23:501-513

Talboys PJ, Heppell J, Roose T, Healey JR, Jones DL, Withers PJ (2016) Struvite: a slow-release fertiliser for sustainable phosphorus management? Plant Soil 401:109-123
Tang C, Longnecker N, Thomson C, Greenway H, Robson A (1992) Lupin (lupinus angustifolius 1.) and pea (pisum sativum 1.) roots differ in their sensitivity to ph above 6.0. J Plant Physiol 140:715-719

Tang C, Robson AD (1993) Ph above 6.0 reduces nodulation in lupinus species. Plant Soil 152:269-276

Vance CP, Uhde-Stone C, Allan DL (2003) Phosphorus acquisition and use: critical adaptations by plants for securing a nonrenewable resource. New Phytol 157:423-447

Veneklaas EJ, Stevens J, Cawthray GR, Turner S, Grigg AM, Lambers H (2003) Chickpea and white lupin rhizosphere carboxylates vary with soil properties and enhance phosphorus uptake. Plant Soil 248:187-197

Zobel RW, Kinraide TB, Baligar VC (2007) Fine root diameters can change in response to changes in nutrient concentrations. Plant Soil 297:243-254. https://doi.org/10.1007/s11104-0079341-2 